\title{
Feminism Interpretation of Joseph Conrad's Works -Taking Heart of Darkness as an Example
}

\author{
Sun Xin \\ Baicheng Normal University
}

Keywords: Joseph Conrad; feminism; interpretation

\begin{abstract}
This paper first discusses the feminism theory in Britain, France, and America, then introduces feminism viewpoints of Conrad, and conducts a detailed discussion on feminism with Heart of Darkness as an example.
\end{abstract}

\section{Introduction to Joseph Conrad}

Joseph Conrad (1857-1924), a British novelist born in Poland, is well-known as the founder of modernism. In his whole life, he wrote 13 full-length novels and 28 short stories, including Heart of Darkness (1899), Lord Jim (1900), The Secret Agent (1907) and so on. In his long period of creation, Heart of Darkness (1899) is the work in earlier period, and this paper interprets this work from the perspective of feminism.

\section{Introduction to Feminism Theory}

Feminist criticism exists in various forms with different pursuit of goals. During the past thirty years, three branches of feminist criticism appear, including French feminist criticism, American feminist criticism and British feminist criticism. British feminist criticism essentially belongs to Marxism, mainly focusing on oppression; French feminist criticism is psychoanalytic school in nature, mainly focusing on suppression; American feminist criticism is text-centered in essence, mainly focusing on discourse and expression. British feminist criticism theory pays more attention to political and social transformation and ideology. Whereas, French feminist critics focus more on analyzing the producing way of language and significance. According to French feminist critics, language is dominated by men, and there are only two choices for women, "to imagine and represent themselves in the way of men, or to occupy vacancy in masculine logic, in this way, they choose to be silent, becoming the invisible and voiceless gender.” French feminist criticism theory is creative when interpreting two kinds of women in narrative discourse by Marlow, the protagonist in this novel. Female, such as the black mistress of Kurtz and local laundry woman, is silent; however, the other kind of women, such as Marlow's aunt, is allowed to make a sound, but only to narrate the myth permitted by men. Compared with French feminist critics, American feminists are more interested in analyzing literature text. "Many people began to re-read great works by male writers and review literature tradition with an attitude of revisionism. These critics disclose male ideology hidden after reading these female characters in these works, and show us how the domain role of men forms in literature tradition.” Gender politics of Kate Millett is exactly the typical case of reviewing. As a "resisting reader", she seeks to describe the part missing in text, undescribed, marginalized or deleted.

Although there are diversified research methods and theories of feminism critics, in general, there are some points in common. In reading strategy, literary criticism of feminism mainly emphasizes experimentalism and female reading experience. Some feminism critics have resisted consciously the systematization of literary theory, especially structuralism and deconstructionism. They view those as paternity methodology. However, with time passing by, modern feminism criticism increasingly focuses on the significance of theory. 


\section{Conrad and Feminism}

Female in Conrad's works gradually become the focus with the publication of Joseph Conrad: Achievement and Decline. The writer, Thomas Moser, influenced by Freud psychoanalysis, exaggerates one-sidedly the Conrad's ambivalence of disliking women because he lost his mother in early childhood, and considers all female in Heart of Darkness as mysterious female embodiment with strong possessiveness and destructive power. With the rise of feminism theory, Conrad's works became the target of public criticism. Radical feminism critics led by Nina Pelikan Straus believe that the trip to Africa of the protagonist in Heart of Darkness is the colonization of female, and female characters are expelled, forgotten and materialized, so they think that Conrad is the male chauvinism writer who vigorously propagate male value system by virtue of his male protagonist. In the novel, he shows the truth to men, but liars to women. The focus of Straus on female topic is recommendable, however, it is unfair to simply equal the writer to the protagonist. There is inevitably some drawbacks since the creation of feminism. In initial stage, it opposes logocentrism, at the same time, it criticizes most male writers. With the deepening development of feminist criticism, this extreme theory is improving. The binary opposition between the creation of male writer and the interpretation of feminism is gradually declining, more and more critics begin to doubt subjective assume of Moser and Straus, and female images by Conrad arouse wide discussion of reviewers.

\section{Feminist Interpretation on the Title of Heart of Darkness}

Among important works of Conrad, Heart of Darkness is the one that repels female and feminism seriously, so it is always considered as the example of criticizing that Conrad is the misogynist. However, this interpretation blurs the difference between the writer, Conrad and the narrator, Marlow, and mistakes Marlow's patriarchal ideology and misunderstanding on women to Conrad. In the novel, Marlow is an unreliable narrator with drawbacks. His description and comment of female with patriarchal ideology always make him be criticized by feminist critics Therefore, this paper will disclose Marlow's misunderstandings on women and his patriarchal ideology hidden. The title of Heart of Darkness is rich with symbolic significance. Critics try to explain its deep implication, some people think it symbolizes the wildness of African continent, and some people believe that it stands for the darkness in human soul. The author thinks that in narration discourse of Marlow, Heart of Darkness represents the close relation between female world and darkness. During a long period, Marlow imprisons female in dark world: two women "are safeguarding the door of darkness and weaving black velvet seemingly for warm shroud"; Kurtz's fiancée "moves forward, in a black suit, and with a pale face, moving in darkness"; and even the portrait of his fiancée by Kurtz is with a dim and dark colored background". In fact, the men-centered culture considers female as the darkness. Freud once called female gender as "dark continent", which is satirized by Hélène Cixous, "As long as women speak and their names are known, they will be informed that their field is dark colored. Because you are from Africa, you are black colored. Your continent is dark, which is dangerous. You cannot see anything in darkness, so you fell scared." So long as the myth about gender exists, Marlow's trip to Heart of Darkness will be a process of invasion and colonization of female field.

\section{Interpretation on Female Images in Heart of Darkness}

Specific cultural background, specific social stratification and specific race boundaries endow human with inherent thinking paradigm. Marlow is the first person narrator in Heart of Darkness, as a white man, has natural general advantage, superior white skin color and inevitably integrates into western undiminished male-dominated power. In Marlow's narrative discourse, dark hear symbolizes female world, and female and darkness are closed related to each other. Two women outside are guards of the gate of darkness, they are weaving black velvet and guiding the route for men. Kurtz's fiancées are in mourning in black suits. In Marlow's narration, female characters are 
silent or marginalized, which indicates the discrimination of patriarchal ideology on female. In his narration, they are full with mysterious color, silent, symbolizing the darkness. In the whole discourse, he deliberately and arbitrarily places female, especially black female outside the discourse, and expels them in the margin of living space. "They, the women, live outside the reality, and should live outside the reality.” Indeed, in Marlow's power discourse, in his deep-rooted ideology, women stay away from the reality and cannot belong to the reality, because the reality is only owned by men. Thus, Marlow narrates women outside the world full with furious ocean, drifting stagnant steamship, mysterious river and jungle and wild and vicious secret anchorage ground. According to Marlow, women live here, but two mysterious black women in black suits, like witches, and a "wild" black woman wearing bizarre ornaments, and their existence is silent. They are excluded outside by men and in passive and soundless space. They are never considered as the same individual as a man, like Marlow, Kurtz or other crew members. In the novel, there are five women in total. In addition to three black women mentioned, there are two white women, Marlow's aunt and Kurtz's fiancée. Reasonably, Marlow seemingly should think highly of these two women and value their existence, because after all, they are noble white people valued by Marlow and have the white culture symbolizing the advanced civilization of human. Whereas, they are women, just women, same to other three women, repelled outside the world of men. In men's opinion, they are same uneducated, romantic and extremely vulnerable, and cannot face the reality of life. For Marlow, his aunt is "innocent, lacing the understanding of truth", because his aunt reminded Marlow to wear thick sweat shirt to the center of the Earth (tropical jungle in Africa). And Kurtz's fiancée, “Intended”, this woman, born in rich family, has elegant posture, beautiful face and graceful temperament, however, lives in "dark space like a tomb for many years, pedantic, boring and lifeless". She is excluded outside in external space, living in Kurtz's shadow, like his belongings. As Kurtz called her name, "Intended", meaning "fiancée" in Chinese, and "desired or planned" grammatically. She does not have her own name, for Kurtz, she does not have any her own characteristics, or her own identity. She is just the carrier of will and dream of the poor white man, Kurtz. With "Intended" as the goal of life and career, Kurtz went to African jungle alone, madly pillaged treasure and exploited money earned by sweat and toil by local black people. Thus, "Intended", like other black women, is enslaved selfishly by men and constrained in her studio, living in Kurtz's space. Besides, she is also repelled outside the truth, tricked by Marlow, and wrongly believes that Kurtz would never forget her name at his death. She does not that Kurtz at that time has already lost his humanity, shouting "Horrible, horrible!" and died. This is probably his repentance for himself, for the world and for what he did in his whole life. However, Marlow deprives the rights of "Intended" to know the "truth", leaving her in a romantic liar permanently. Marlow further consolidates the barrier to disconnect her relation to the outside world and destroys the possibility of her disillusion, leaving her in limitless virtue world forever. In addition to the scorn of women innocence and fantasy, there is malicious scorning for black women in Marlow's narrative discourse. In his eyes, that “wild” black woman (Kurtz's mistress) is full with the alluring and horrible evil. He blames Kurtz's distortion of Kurtz's humanity and appearance to the double "other" identity of this black woman, wildness and woman, thus, being in binary opposition to civilization in his male-dominated discourse and men. In the novel, Marlow describes the original lust unconcealed of the "wild" woman and public blame for Kurtz as vicious lure, danger, greed and evil. She seemingly becomes a brutal vampire, and Kurtz, the symbol of civilization and power, died because of her lure. The double characteristics of "wildness" and "woman" stain and destroy original advantageous gender and civilization of men, also the cause for Kurtz to be indulged in vicious and bloody jungle and abandon civilization and "Intended" who miss him all the time. Thus, Marlow shows his own advantageous feature, that is the power of men and the ruling of men. He cannot be tolerant of the constraint for men by women. So in his discourse, he then tries his best to reduce the power of "wild" woman and disclose the miserable, hopeless and passive inner world of women with the tragic sorrow of women in the death of her lover. "She stopped, like her heart stopped beating." Finally, Marlow puts the tough woman into the same place as "Intended", in permanent sorrow and self-constraint. "It is strange that woman should stay outside the truth like 
this, living in their own world. There has never been such thing in the world, and never will.” This contradictory discourse ignored by Camon critics discloses the scorn for the existence of female by Marlow and other male characters in the novel. Marlow again puts the existence of female in soundless, helpless and egoless silent world.

The novel seeks to construct a binary opposition of gender from the beginning to the end, where all female characters are marginalized, tiny and docile, easily and willfully controlled and ruled by male images, without any self-concept or consciousness of resistance. In this way, females become the vulnerable object of patriarchal social system, existing as the silent other one contrary to males and controlled by them. Kurtz's fiancée lives silently like this all the time. "Her expression in her eyes are straightforward, deep and confident, and relying on others. She keeps her sorrowful face high, like being proud of her grief, and like saying I, only me, knows what kind of mourning he deserves." She lives for Kurtz forever, and even after his death, she is in mourning as usual, willingly keeping chaste for him. What's more, in patriarchal society, women are endowed with innocent feature, blindly following the manipulation of men. Marlow notices a small oil painting pined in a woodblock, and there is a woman putting clothes on, eyes closed, and holding high the torch. The background is dim, nearly in utter darkness. The action of this woman is dignified, however, the torch light shining on face shows auspicious omen, which indicates the innocence of women in patriarchal society, completely manipulated by men, and foreshadows the tragedy of Kurtz's fiancée. She blindly worships his fiancé, “eyes closed, holding high the torch” forecasts that she blindly supports his colonization career, staying at home alone for him, and after his death, she worships him and upholds her belief. She lives in her innocent world permanently, a virtue world. She never doubts his hero and decides to stay chaste for his man. At the same time, she also hopes everyone else shall have the same idea with her that he is a hero.

\section{Conclusion}

In conclusion, with the introduction to feminism theory and analysis on female images in Heart of Darkness, it is known that Conrad conducts the "othering" and "marginalization" on women by virtue if Marlow's discourse, which is the doubt and criticism of the value system in late Victorian era.

\section{Acknowledgement}

This work is one of concluding results of "Research on Joseph Conrad's Works from the Multi-culture", the 12th Five-Year Plan project of The Education Department of Jilin Province. Project No.: JJKWHZ [2015] No. 368. Project Host: Sun Xin.

\section{References}

[1] Bai Meixian. To Break through the Tradition: Feminism Interpretation of Heart of Darkness [J]. Journal of Liaoning Educational Administration Institute, 2016.

[2] Ding Yan. On Conrad's Feminist Consciousness in "Heart of Darkness" [J]. Journal of Zhejiang Wanli University, 2007.

[3] Zhang Yunfeng. Female in Margin -Research on Female Images in Conrad's Novels [J]. Journal of Shayang Teachers College, 2006. 